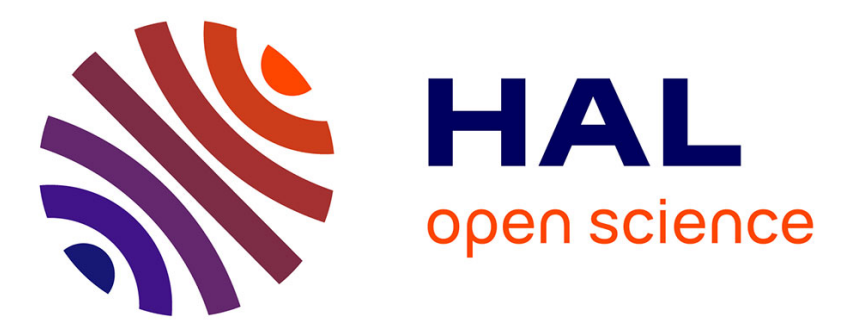

\title{
Disarmament for development in favour of developing countries
}

Jacques Fontanel

\section{To cite this version:}

Jacques Fontanel. Disarmament for development in favour of developing countries. Disarmament and Economics, Essays in honour of Jan Tinbergen," University Den Haague, University of Rotterdam, ECCAR, May 1992, Den Haague, Netherlands. hal-02373424

\section{HAL Id: hal-02373424 https://hal.univ-grenoble-alpes.fr/hal-02373424}

Submitted on 21 Nov 2019

HAL is a multi-disciplinary open access archive for the deposit and dissemination of scientific research documents, whether they are published or not. The documents may come from teaching and research institutions in France or abroad, or from public or private research centers.
L'archive ouverte pluridisciplinaire HAL, est destinée au dépôt et à la diffusion de documents scientifiques de niveau recherche, publiés ou non, émanant des établissements d'enseignement et de recherche français ou étrangers, des laboratoires publics ou privés. 


\title{
Disarmament for development in favour of developing countries
}

\author{
Jacques Fontanel \\ Disarmament and Economics, Essays in honour of Jan Tinbergen, \\ Economists Againts Arms Race, \\ Den Haague , 21 - 23 May, 1992,
}

Analysis of the economic advantages of disarmament has been reduced to the dictum "guns or butter". The majority of economists have analyzed military expenditure as unproductive, as a burden to be minimized to the greatest extent commensurate with security constraints. Ceteris paribus, a decision to disarm was seen as a good procedure for an improvement of economic growth. The thesis has been disputed by such widely differing economists as Adam Smith, Robert Malthus, Karl Marx, Friedrich List, John Maynard Keynes or more recently John Galbraith, Wassily Leontiev or Lawrence Klein.

The present disarmament process is highly exceptional. In a situation of economic crisis, discontent grows. It becomes more difficult to run a heavily militarized economy. In this context, there are three different interpretations of disarmament:

- First, disarmament may be concerned with the reduction of excess armaments. Consequently it turns out to be necessary to analyze the concept of excessive stocks of weapons. The main problem is to define the new explosive power of a dollar (the "bang for a buck"), when a prohibition of the production of specific weapons is decided by the main states. A disarmament process leads to a modification of the military strategies and a ban on the production of some weapons alters the relative power of the Nations. The main question is : "how much has to be spent and in what new way must it be spent ? But, first of all, destroying missiles is a costly business. Disarmament, taking the form of the destruction of military materials, appears as a short run cost. Any possible transfers of resources should initially serve to offset the costs of this collective decision.

- Next, disarmament can be imposed by disastrous national economic conditions. There is a choice between guns or butter. It has been stated that national security can no longer be analysed in purely military terms. Economic security must also be taken into account. Governments are beginning to ponder the economic effectiveness of the arms race. 
- Lastly, disarmament presupposes a real process of the reduction of the opposition between different forces, without reference to massive stocks of weapons, but with the idea of establishing a lasting peace able to overcome the ideological, political and religious conflicts. This is the situation most favourable to true disarmament.

Disarmament and development are two essential objectives of our time. What we need to know is whether it is desirable that they should be linked. The economic theory of disarmament for development is still to elaborate. In this context, our analysis is concerned with three main issues :

- the feebleness of the economic theory of Disarmament for Dévelopment, - the relations between military industry and growth in Third World countries, and

- the relation between disarmament and development in the developing countries

\section{1) The feebleness of the economic theory of Disarmament for Development}

States have to protect their wealth or run the risk of being deprived, ultimately, of their rights over the distribution of the world's wealth. There is, therefore, a choice to be made between today's and to morrow's security, a choice dependent on the nature and strength of international tensions. The possible effects of disarmament are not confined to the improvement of the macroeconomic results of the country concerned. They also modify the distribution of the advantages of growth, and effect a partial redistribution of the cards of international competitiveness.

For the great majority of economists, disarmament involves a reduction of military expenditure. This hypothesis is not always true, especially when there are some short run costs for the destruction of weapons or when the process of disarmament is based on the reduction of the number of weapons, notwithstanding their quality. Moreover, military expenditure may be regarded as a variable that is half endogenous and half exogenous. Some marxist authors consider that military expenditure serves both to offset the weakness of internal demand (Cypher, 1974; Krell, 1981), to soak up the surplus that monopoly capitalism secretes (Baran \& Sweezy, $1966)$, or to weaken the socialist economies obliged to accept the arms race in order to survive (Gerbier, 1984). More generally speaking, several economic determinants of military expenditure have been discovered: 
- There is a positive relationship between the civil budget of the state and military expenditure (Lotz, 1970; Harris, 1986; Fontanel, 1980). It would appear an inertial effect inducing governments to set military expenditure at a more or less constant proportion of the public budget from one period to the next;

- Military expenditure is often seen as an economic burden. The larger the per capita income in a country, the less, proportionally, is the state inclined to increase its military expenditure (Lotz, 1970).

- Military expenditure is dependent on development, urbanization, the availability of petro-dollars giving way to the "demonstration effect" in emulation of richer countries (Deger \& Smith, 1983) and acyclic movements of the economy (Griffin, Wallace \& Devine, 1982; Galbraith), in particular the attempt to maintain full employment in the short term (Smith \& Deger, 1983). The existence of a military and industrial complex tends to have a positive effect on military expenditure (Melman, 1974; Kidron, 1970; Griffin, Wallace \& Devine, 1982). Hewitt (1990b) shows military expenditure to be dependent on economic, financial, political and geographical variables. It remains the case that factors other than economic ones are more generally advanced as explanations for military expenditure. They include the bureaucratic procedures involved in the allocation of military resources (Treddenick, 1985), ideological struggles (Thee, 1982), elections (Nincic \& Cusack, 1979), the power struggle ( Grindle, 1986; Griffin, 1982), changes in society (Grindle, 1986), dictatorship (Kende, 1980), the militarization of society (Maizels \& Nissanke, 1986; Thee, 1982; Whynes, 1979), the arms race (report of the United Nations on the Economic and Social Consequences of the Arms Race ..., 1982), strategy (Fontanel \& Smith, 1990e) and imperialist rivalries (Gerbier, 1984; Thee, 1982). Although governments do make choices over military expenditure, their freedom of choice is very limited by all the partial cause variables.

There are three main theories of disarmament for development :

I.1. Disarmament analyzed as a political factor and as an economic investment ;

I.2. Disarmament analyzed as an illusory procedure within the capitalist system ;

I.3. Disarmament as an ineffective tool for economic development. 


\section{I.1. Disarmament analyzed as a political factor and as an economic investment}

For the classical British economists, war and preparation for war are explicit variables of the monopoly spirit, on which grounds both Adam Smith (1776) and David Ricardo (1817) were to condemn mercantilist thought dominated by the hegemonic drive of the ruler. Armed conflicts are analyzed exclusively as political phenomena. Nevertheless, it is advocated that armed forces be established to ensure the sovereignty of the states threatened by less developed economies. Generalized development precedes disarmament. These ideas were to be picked up by the French liberals and the utopian socialists (Saint-Simon, Fourier, Proudhon). They even developed the idea that war was tending to disappear with the emergence of the industrial class, because this class was eliminating pauperism. For modern liberal economists, disarmament is conducive to development but, conversely, generalized disarmament is impossible in the absence of universal economic development. Nef (1949), for example, thinks that peace stimulates the economic activity of the states, while Seymour Melman (1971), in counterpoint, stresses the harmful effects of military expenditure on the American economy like loss of competitiveness, development of the bureaucracy, reduction of productive investment, and the appearance of military-industrial complexes. As far as neo-classical analysis is concerned, there is in every society a function of social wellbeing that is maximized under constraints. Expenditure on security contributes to the definition of this optimum. The theories of models of the arms race such as the model of Richardson (Brito \& Intriligator, 1967) demonstrate that budgets preparing for war increase the likelihood of war. Then, disarmament is both useful for peace and economic development.

\section{I.2. Disarmament analyzed as an illusory procedure within the capitalist system}

- War and conflicts relate to the superstructure and are conditioned by antagonistic social relations. For Marx and Engels (1860), peace and disarmament have no intrinsic moral virtue. Disarmament is desirable only if capable of producing economic development induced by the radical break with capitalism. Rosa Luxembourg (1913) considered military investment to be useful for the development of capitalist economies, as a catalyst of primitive accumulation, as an instrument of colonial domination and lastly as a hegemonic factor of the struggle between the capitalist countries to divide up the world. Lenin (1916) also thought that imperialism, the 
highest stage of capitalism, necessarily stigmatized by total wars and the capitalist exploitation of the world, ruled out any non-economic disarmament process without the advent of socialism. These theses have been taken up by contemporary authors. Baran and Sweezy (1968) argue that military expenditure serves to absorb the economic surplus that monopoly capitalism secretes. The thesis of the economy of continuous arms (Kidron, 1970) takes the view that military expenditure exerts a positive influence on profits, on capitalist technology and on the demand for labour. Military strength enables other nations to be exploited, either through the occupation of territory, or through intimidation, or through the giving of power to national collaborators. As conflicts are inherent in capitalism, disarmament is not possible within this economic system.

\subsection{Disarmament as an ineffective tool for economic development}

Disarmament cannot be accompanied by development. For mercantilists, the might of the Prince is the basic objective of any national economy (Silberner, 1957). It is always preferable for a nation to be less rich if the other states are proportionally poorer. Victorious war enriches the State. Under such conditions disarmament is not acceptable for superpowers. The modern analyses of game theory applied to international relations (Brewer \& Shubik, 1979), the thesis of unequal exchange (Emmanuel, 1969), the theory of underdevelopment as a product of the development of the great powers, and concepts of economic warfare (Baldwin, 1985) are all theories that perpetuate this economic analysis in terms of power. Bouthoul (1961) regards war as a necessary factor which reduces the excessive population growth. These functions of socio-demographic rebalancing and readjustment are irreplaceable. Mandel (1975) considered that conflicts or threats of war accelerate technical progress and eliminate unemployment by creating an artificial shortage. Colonial wars are historically seen as basic causes of underdevelopment (Fontanel, 1990d). They promoted export products to the detriment of the crops that provided food for the population, and they had the effect of stimulating the mining industry and destroying local craft industries. These unequal relationships of strength have still not really been challenged, as is shown by the relative stability prevailing in the poorer regions that are largely dependent on spheres of influence inherited from the antagonisms of the great powers and from colonization. The economy has become an instrument of power in the relations of conflict between states. 
Insecurity is dependent on the arms race, on inequality, international domination, and even social exploitation. Indirect strategies of dissuasion, economic forms of retaliation, embargoes and boycotts are all powerful weapons with economic and political effects dependent on defence measures, international expressions of solidarity and the potential for substitution (Baldwin, 1985). Economic weapons are used with the aim of weakening the potential enemy. Direct (military) strategy is made difficult by the strength of nuclear forces and by the doctrine of the balance of terror. There are four main strategies :

1) Impoverishment resulting from the strain of preparing for war is often presented as one of the basic reasons for the collapse of the Soviet economy. An arms race reduces the development potential of the states, but the poorest are the most rapidly impoverished, with the result that the power of the richest countries is increased.

2) The strategy for effecting the break ("rupture") is Manichaean. The aim is to create economic problems in the rival country so as to increase its political and social difficulties. An embargo is an instrument of dissuasion capable of changing the behaviour of a potential enemy, but it is a weapon that is dangerous to the user.

3) The aim of the containment strategy is to develop ties of economic interdependence capable of ensuring peace. The dissuasion of aggression stems from the new economic interdependence thus created. In particular, it was long considered in Ostpolitik that commercial ties had a moderating role on ideologies.

4) The aim of the strategy of political violence is to take economic power when it is hostile and progressively to weaken the dominant social groupings. The political forces of the machinery of the state and the trade unions must be brought under control to that end.

To sum up: any disarmament procedure that does not confine itself to the reduction of excess levels of armament does not necessarily lead to human and economic progress.

\section{II) Military industry and Third World Development}

Development is a broader concept than growth; it also introduces the idea that well-being is irreversible or that entitlement is flourishing (Sen, 1983). The question is one of knowing whether or not a prolonged military effort is a brake on economic development. Saadet Deger (1986) thinks that there is a negative relationship between socio-economic development and military influence, even if this basic hypothesis is not always supported by oversimplifying econometric studies. There are at the 
present time four main approaches to economic development: the seeking of comparative advantages through the easing of restrictions on trade; development based on exports; the expansion of industrializing industries; and the policy of import substitution.

\subsection{The easing of restrictions on trade}

It affords little opportunity for developing countries to attain their own independent advanced arms industry. Liberal theoreticians take the view that the opening of economic frontiers is egalitarian in promoting economic and social progress and favourable to peace. Every country ought to specialize in products for which it is reasonably cost-effective. It is pointless to produce arms for their own sake, because the trader and the manufacturer ought to supplant the warrior. The production of the arms essential to security ought to be carried out in allied states that have the best comparative advantage.

Vernon's theory of the product cycle stresses the progressive transformation of the world economic landscape, a feature of which is the irreversible trend for some sectors of industry of the developed countries to shift to the developing countries. In its first phase the new product is manufactured in the developed countries, which are havens of scientific and technical research and are the principal purchasers. The developed product is better known, and demand for it increases considerably owing to the diffusion of technology and the appearance of new competitors. The product becomes increasingly international and the conditions are established for the manufacture of the standardized product, with a good knowledge of the manufacturing processes and their simplification. If the labour input of the product is heavy, the price elasticity high and the transport cost low, the developing countries are able to gain a place in the market. These products even have a tendency to drift outwards. The manufacture of traditional weapons that change little, are not shrouded in military secrecy and do not require sophisticated manufacturing processes. They may follow Vernon's cycle. However, the developing countries are unable to take over production of the arms needed for their security ; their production responds above all to purely economic considerations and is confined to ordinary munitions. Were one or two countries to prove to be the most competitive in this sector, it is likely that after several years of near monopoly they would progressively use this power to subjugate all their customers. The arms industry is not an activity like all the others, but one that calls security and freedom into question. 


\section{II.2. The policy of import substitution}

It seeks to replace imports by a product manufactured within the country. It was at the outset a matter of ensuring the manufacture of imported intermediate goods and consumer durables. The principle of the theory is simple : given that an internal demand exists, what has to be done is to produce locally what is bought abroad. In this sense, the pursuit of endogenous development is opposed to liberal theories based on comparative advantage and the contributions of factors.

In the early seventies there were many agreements for the manufacture of arms under licence. If it is true that arms production is favourable to national supply industries, it also permits the penetration of foreign capital and the conversion of military industries into transnational industries. This policy is nevertheless estimated to economize on scarce foreign currency. Purchases of munitions are sometimes the source of a deficit that may have grievous consequences through its effects on speculation, worsening of the terms of trade, and the emergence of cumulative effects that aggravate the deficits and inflationary tensions.

Nevertheless, the arms industry does not really promote economic growth and even less does it promote industrial integration because the multiplier effects are, empirically, fairly weak, the divorce between civilian activities and military activities, the fact of military secrecy, and the economic dislocation. It may lead to a very considerable increase in costs, to dependence for intermediate consumables and patents, to a break between the protected military sector and a civilian sector in a competitive situation, and to eviction effects to the advantage of military activities etc. But, in the absence of reliable military research and development, the security of countries is under constant threat, unless it is covered by a military alliance. Technological competition, which is unending, accelerates obsolescence. Since the developing countries are obliged to seek foreign licences, it is difficult for them to assert their economic independence.

\section{II.3. The strategy of development through exports}

This strategy is extremely dangerous when applied to the military sphere. The trade balance will not necessarily benefit, at least not initially, since allowance must be made for the imports required for the manufacture of national equipment (more than 30 per cent of the cost of the military 
equipment exported by France) for the price competitiveness of nationally produced arms in relation to their foreign counterparts ${ }^{1}$ and for timelags ${ }^{2}$

The need to export in order to cut costs by economies of scale also gives rise to economic dependence. The exporting of arms is often regarded as a highly lucrative activity. In fact, this function appears to have been quite poorly fulfilled for the past several years. Sales are in effect accompanied by credit conditions that are especially favourable to the purchaser, and sometimes they do not involve any reciprocal financial transactions, notably for heavily indebted or developing countries ; furthermore, some equipment is on occasion sold more cheaply abroad than to the country's own armed forces. Indeed there is such a thing as impoverishing exportation, i.e exports that tend to weaken the country economically, particularly when they are worsening the terms of trade. Lastly, with regard to the requirements of purchasers, the economies of scale expected to accrue from serial production are not always very great, except for very ordinary equipment from which little profit is expected, by virtue of the competition. A decision to disarm would then be highly prejudicial to the national economy as a whole. Under these conditions, there would evidently be less scope for the application of policies of import substitution or of the principle of industrializing economies; the return on investment would be so slow as to cause serious problems of survival and conversion to the companies.

\section{of development \\ II.4. Arms industries as industrializing industries or poles}

From Galileo to Papin, and including such scientists as Newton, Bernouilli, Euler and Leibniz on the way, many scientific discoveries have been due, in origin, to the problems raised by the art of war. There are many theories stating that such militarization is able to have positive effects on the national economy. Lewis Mumford even thought that only the military sphere and war offered sufficient scope for the use or absorption of the output of the new capitalistic installations. The army was a consumer perfectly tailored to the industrial system and the economic interests of industrialists and the military were

\footnotetext{
1 At the cost of temporarily replacing a deficit of the trade balance by a budget deficit or of redistributing public expenditure.

2 Purchases from abroad are rarely paid for in cash, but imported components for military equipment are, which may cause unacceptable bottlenecks.
} 
complementary. This was the first version of the idea of the military and industrial complex. There are many factors that support this thesis, for example the rational model of management and the application of Taylorism in military arsenals. Industry has learnt a great deal from war with respect to organization, discipline, standardization, the coordination of transport and supply operations, the separation of functional and hierarchical services, and the division of labour.

In contrast to the Second World War, the authorities began to invest in science for security reasons. The post-war period was even marked by the pursuit of scientific secrecy, by the capacitation of defence, and by a massive influx of scientists into the military-economic complex. The national economy and the national science would henceforward be at the disposition of the government. The war had taught scientists and other academics to work together and had shown them the effectiveness of team research; it had also brought about decisive changes in the method, spirit and the scale of laboratory research. Scientists sometimes found themselves hostages, caught between the desire to continue their research and the more readily available funding in the military sector. Recently this procedure has been more maintained with the Strategic Defence Initiative (SDI). Only one per cent of the patents developed by the Navy have actually become the object of licensing agreements. The arms race became chiefly responsible for the chaotic development of the sciences and remained so until the 1980s, when Germany and Japan were to open up new paths little explored by the other powers, which had been too much preoccupied with their military leadership.

There is an idea that has been strongly developed in Brazil and India. Economic development must be brought about through stimulating investment, since it is impossible, initially, to achieve harmonized and balanced development. What is therefore needed is to invest in activities that have the effect of providing an impulse through sequences of induced investments that ensure vertical and/or horizontal complementarity of the country's industry. The effectiveness of investment is measured by these induced knock-on effects. In this sense, military industry is a pole of development either through the backward linkage effects (which reveals the increased demand of all the production sectors feeding the sector in which the investment is made) or forward (which is felt further down the line) linkage effects. Production of military equipment stimulates the civilian sector through the purchase of intermediate consumables on the internal market and through the creation of new jobs. Nevertheless, these stimulating effects are not decisive for development, 
since there is considerable risk of obsolescence in an economy in which there is already little innovation.

There is considerable risk in exporting to achieve acceptable economies of scale, except for products that provide little stimulus. The risk of penetration by foreign capital is far from negligible, and military industries make great demands on capital, which a scarce factor of production for Third World countries. Arms production leads to militarization of the economy and reduces the disarmament potential. It cannot be denied that whole groups of national industries may go rapidly into recession unless military orders are replaced without delay by civilian orders. It is also logical to expect that positive effects will emerge from disarmament, possibly in other sectors or other regions.

Furthermore, the changeover from military activities to civilian activities right on the industrial site is a particularly delicate operation, because the equipment is unsuited to the constraints of civilian demand. Two basic economic reasons are usually advanced to justify arms industries: the saving in scarce resources and the industrializing effects. Analyses of import substitution policies and of industrializing effects are not very encouraging in this respect. The opportunity costs of using highly skilled personnel in the military sector, the heavy investment involved, the pace of innovation and the rapidity of obsolescence in the military sector, the imports necessarily occasioned, the length of the production cycle, the intervention of multinational corporations, and the weakness of the industrial base needed if the best-performing products are to be competitive are deterrents at the purely economic level against national production of arms in developing countries.

\section{III) Disarmament for Development in Favour of the Developing Countries}

It may be recalled that successive French governments ${ }^{3}$ have frequently called for the establishment of an international fund of disarmament for

\footnotetext{
3 In his speech of 28 september 1983, François Mitterrand set the following agenda : 1) to measure the military burden and to overcome the differences on data and estimates to obtain a standard accepted by all ; 2) to estimate the economic effects, domestic and international, of the growth of military expenditure ; 3) to measure the relation between the evolution of military expenditure and the main factors contributing to international economic disorder ; 4) to examino the possibility of meeting social goals (health, technical training. agricultural development in the Third World using the
} 
development that would enable the amounts saved on arms to be used to develop productive activities that would speed up economic development and extend it through aid arrangements to the developing countries (Klein, 1990; Fontanel \& Smith, 1987).

Disarmament for development is generally analyzed, on the one hand, in the absence of any international transfer of the resources saved through disarmament and, on the other, in the context of increased aid for the most destitute countries.

\section{III.1. The Internal Effect}

If military expenditure is unproductive, it follows that anything that tends to reduce it while maintaining an equivalent level of security is economically desirable. Nevertheless, it cannot be denied that considerable problems may arise as a result of ongoing disarmament: increased unemployment for young conscripts who are not called up; a reduction in the number of jobs for military personnel whose abilities are sometimes too specialized to be easily fitted into the civilian economy; reduction in the activity of garrison towns and arsenals (Dunne, 1986)

The well known study by Benoit (1978), partly confirmed by Frederiksen and Looney (1982) suggested that military investment would be conducive to industrial modernization, to training and knowledge, to the improvement of infrastructures, to full use of the productive capacities of the economies of developing countries, and to the sense of order and discipline. This study also suggested that the desire for independence would not be an obstacle to economic development. Both the form (Deger \& Smith, 1983) and the content has been strongly questioned by a lot of economists. This relationship is basically highly disputable, because there is a considerable difference between the modernization of defence forces and of the economy. It even happens frequently that competition develops

\footnotetext{
resources freed by an organized progressive reduction in military expenditure in the major countries. The UNIDIR puts forward tour essential principles :

- All proposals for such a Fund must rest on the willingness of the great power to disarm.

- It is necessary to deline a form for the Fund which promote longer term progress towards international security through development and disarmament.

- The Fund should serve as an institutional link between disarmament and development ; a link which has not been systematically developed in any international institution, past or present.

- The Fund would require co-ordinated action among States. Each country will need to perceive participation in the Fund as being in its own interost.
} 
between the military sector and the civilian sector over the hiring of the best skilled personnel, and under those conditions the effects of eviction reappear as strongly as those initially affecting the formation of civilian capital. Whereas military expenditure has a positive effect on growth in the short term, through reduced savings, it has a negative impact on economic development in the longer term.

There are three crowding out effects in countries in which resources are scarce: temporal (the choice between the present and the future), sectorial (the choice between the military and civilian spheres) and by category (the investment crowding out effect caused by defence expenditure). Augusto Varas (1986) considers that the effect of military expenditure differs with the development level of countries, influencing the material well-being of Third World countries and the growth of developed countries. The militarization of developing countries is not conducive to their economic development in the long term (Smith \& Smith, 1983), despite the mobilization of the surplus to which it may give rise. The substitution relationship between investment and military expenditure which is henceforward quite generally accepted for developed countries, at least when the strategic threat is quite weakly perceived by the private sector, is less accepted for the developing countries, which suffer the pangs of chronic underconsumption. Other effects may be involved. For example, military infrastructures may be suitable for civilian production, and demobilized soldiers back in civilian life are capable of improving national productivity. Nevertheless, Gyimah-Brempong (1989) is of the opinion that the military expenditure of African countries is not capable of stimulating economic growth, since the positive effects often instanced are largely offset by the reduction of investment occasioned by this defence effort.

Saadet Deger (1986) and Nicole Ball (1988) regard national armament as a cause of underdevelopment, whereas Robert Looney (1988) thinks that this relationship can really be accepted only for countries that are not arms producers. Looney's econometric results indicate that: (1) political and administrative influences do more to determine military expenditure than do international rivalries; (2) the substitution effects are greater in arms producing countries than in countries that merely import the arms that they need for their defence; (3) military expenditure has made only a slight contribution to the increased indebtedness of Third World countries. Nevertheless, no Third World country is capable of sustaining such a policy unless it already has a sufficiently strong and diversified industrial sector (Wulf, 1983). Lastly, the growth of arms industries in the developing countries also leads to an increase in military expenditure 
which, in the long term, can raise serious difficulties in national economic development (Fontanel and Saraiva, 1986). Even so, Michael Ward (1991) demonstrates that the military programmes in Brazil and India are tending to be globally positive. If account is taken of the fact that other public expenditure is even more satisfactory for growth, opportunity cost is a question that still has to be considered.

In the absence of transfers and for countries that do not have an arms industry, the effects of a reduction of military expenditure will be positive even in the short term, provided that there effects are not offset by an equal or greater expenditure on the maintenance of internal order or on the purchase of imported luxury goods. For arms-producing countries, disarmament may have perverse effects in the short term, particularly for the industries and regions directly involved in the industrial activities of armament. The economic impact should be positive in the long term, provided that the situation of economic decline triggered by the reduction of internal arms purchases does not lead to irreversible effects, especially related to regards conversion of activity. Basically, disarmament appears to have favourable effects on the national economy in Third World countries, even if the arms-producing countries risk experiencing some difficulties of conversion in the short term. These difficulties will be largely offset by the reduction in imports related to the military industrial effort and by the matching increase in civilian public expenditure.

The effects of disarmament cannot be measured in isolation from the economic policies implemented by governments. A voluntary reduction in military expenditure cannot be realised with "all other things being equal" type of reasoning. The theory of underdevelopment as a product of development takes the view that the economic situation of Third World countries may worsen if, for example, reconverted enterprises in the developed countries enter into competition with national products, or if the developed countries cease to buy the raw materials that constituted the greater part of their export resources. The conversion from military to civilian activities may, however, lead to a search for new outlets and to increased competition for the products of the Third World countries. Similarly, a reduction in expenditure on military research and development to the benefit of the civilian sector may widen the technological gap and lead ultimately to greater economic inequality.

\section{III.2. International Aid}


The question is differently analyzed when the military effort is the resources by assistance from a developed country. Partial transfers of Great Powers economized by a reduction in the military expenditure of the Irrespective of have positive effects on the Third World countries. stem from disarmament in international relations that would interdependence, aid linked to and improvements in international effects as the existing traditional forment should normally have the same

- There are no grounds for expecting the influence of aid to be greater or less, except perhaps at the level of the size of transfer, which may exceed the threshold above which the solidarity accorded has significant economic effects. It should, however, be noted that not all transfers are equally favourable to the economic development of destitute countries. Disarmament can have favourable effects on economic development only if the saving that it makes possible is not confiscated by social groupes that decide to devote it to unproductive uses (exports of capital or imports of luxury goods, for example). In other words, a transfer makes economic sense only if it finds expression in a highly productive activity. A transfer may on occasion be capable of having an adverse effect, notably by aggravating inflationary trends due to the appearance of demonstration effects. A resource transfer may also be the occasion of new markets for the developed countries and new dependence for the poor countries. Thus, James Lebovic (1988) succeeded in demonstrating that political and military considerations were just as uppermost in American foreign aid during the presidency of Carter, with its heavy emphasis on defence of human rights, as during that of Reagan, when the pursuit of the military might essential to American security was a strong influence.

- Transfer therefore satisfies political and military considerations, in the first instance, then come the economic interests of the donor, and only developing countries development needs of Third World countries. The whole, it is impoverishing. nonconvertible currency, the recipient the transfer be made in a the donor country, which may take a country will be obliged to buy from trade flows. Should the trans to reintroduce unequal product concerned satisfies the in kind it may not be evident that the countries. For example, if the aid relolopment needs of the recipient directly or indirectly with the natid relates to a commodity that competes end result may perhaps be very negative industry of the poor country, the so because every product very negative for the Third World, all the more values of the society in which it was stamp of a culture and the dominant 
- Lastly, aid from developed countries may lead to distorted development, especially if it is not disinterested. Some forms of transfers prove ultimately to be costly, notably in operating costs, and political constraints are rarely absent from such an undertaking by rich countries. Furthermore, "aid to developing countries may be devoted to prestige expenditure, to the increasing of social inequalities, and to furthering the development of societies in which human rights are not necessarily respected. Transfers may also be the subject of sordid calculations of interest tending to accustom populations to a type of consumption that renders them dependent on the industrialized countries..." (Fontanel, 1984). Taken overall, the results are favourable to disarmament for development because, although the developed countries may experience a slight reduction in their growth rate in the short term, the effects tend to be positive in the longer term. The result is to narrow the disparities in growth that would exist in the absence of such a transfer. The question then becomes is to find out whether the developed countries desire such an outcome, it being understood that disparities of income are interesting indicators of the satisfaction of the needs of populations.

\section{III.3. In the World Economy}

A reduction of military expenditure has been simulated in several models of the world economy, five of which yield interesting results.

1. The transfer of resources to poor countries furthers their economic development in the model of Leontieff and Duchin (1980a,b, 1983). Disarmament for development is therefore desirable. Ongoing disarmament would have a positive effect for all the regions of the world and the transfers of resources would appreciably increase consumption and the per capita GDP of the arid countries of Africa, and the low-income countries of Asia and tropical Africa.

Three scenarios of the evolution of armament expenditure and transfer of the resources made available were tested (inter alia): The Base scenario represents a projection of the arms race at the beginning of the eighties, leading to world military expenditure in the year 2000 of 646 billion (1970) dollars, purchases of military equipment of 266 billion (1970) dollars, and an arms trade of 37 billion (1970) dollars;

DIS1 represents a disarmament process with the United States and the USSR at parity, making use of only two-thirds of the military expenditure of the Base scenario. The financial defence effort is also 
reduced for the other countries by an amount of the order of 25 per cent for 1990 and 40 per cent for the year 2000;

DIS2 takes the same figures as DIS1, but introduces the transfer of resources from the developed countries to the poorer countries (45 per cent for the low-income countries of Asia, 30 per cent for the countries of tropical Africa, 15 per cent for the arid countries of Africa and 10 per cent for the Latin American countries with middle-level incomes), up to a limit of 15 per cent of the amounts saved through the reduction of military expenditure for 1990 and 25 per cent in the year

Table 1. Per Capita Gross Domestic Product (in 1970 dollars) for the as indicated by three scenarios of military expenditure

\begin{tabular}{|l|c|c|c|c|}
\hline Country or group & DIS1 & DIS2 & Base & $\begin{array}{l}\text { Growth rate } \\
\text { (BASE/GDP 1970) }\end{array}$ \\
\hline Eastern Europe & 4891 & 4894 & 4745 & $203 \%$ \\
\hline Japan & 6805 & 5801 & 6734 & $252 \%$ \\
\hline North America & 7937 & 7937 & 7814 & $69 \%$ \\
\hline Oceania & 5412 & 5411 & 5386 & $93 \%$ \\
\hline USSR & 5790 & 5791 & 5635 & $215 \%$ \\
\hline Western Europe, high income & 5924 & 5922 & 5859 & $127 \%$ \\
\hline $\begin{array}{l}\text { Western Europe, moderate } \\
\text { income }\end{array}$ & 996 & 980 & 940 & $35 \%$ \\
\hline Southern Africa & 1320 & 1320 & 1320 & $68 \%$ \\
\hline Latin America, high income & 1455 & 1375 & 1338 & $202 \%$ \\
\hline Latin America, moderate incom & 4488 & 423 & -418 & $-30 \%$ \\
\hline $\begin{array}{l}\text { Oil-Rich Middle Eastern \& } \\
\text { African countries }\end{array}$ & 3888 & 3868 & 3951 & $1280 \%$ \\
\hline Tropical Africa & 382 & 251 & 244 & $46 \%$ \\
\hline Arid countries of Africa & 353 & 163 & 143 & $-30 \%$ \\
\hline Asia Planned economies & 372 & 372 & 380 & $-14 \%$ \\
\hline Asia, low income countries & 190 & 140 & 136 & $128 \%$ \\
\hline
\end{tabular}

However spectacular these results may seem to be for the sparsely populated underdeveloped countries, they are not statistically very significant. Thus, an annual reduction of military expenditure by $1.2 \mathrm{per}$ cent between 1980 and the year 2000 would further the economic growth of almost all countries (except for the OPEC countries), by 1 per cent for 
Japan, 1.5 per cent for North America, 3 per cent for Europe, 10 per cent for the planned-economy countries of Asia, 20 per cent for the lowincome Asian countries and tropical Africa over a period of 20 years. It may be noted that aid for development appreciably improves the situation of the poorest countries. However, the discrepancies of growth and development tend to increase strongly during this period, which makes the reduction of international tension extremely hypothetical. In opposition to the hypothesis of a decline in the demand for raw materials following a reduction in military expenditure, the model of Leontieff and Duchin shows that the new growth generated by this disarmament does not endanger the economy of the countries that produce raw materials, most of which belong to the Third World.

Table 2. Evolution in the Demand for Raw Materials Under Conditions of Disarmament or Maintaining the Arms Race

\begin{tabular}{|c|c|c|}
\hline Resource & Maintaining the arms race & Disarmament \\
\hline Nickel & 3.1 & 2.2 \\
\hline Copper & -0.3 & 2.4 \\
\hline Zinc & -0.3 & 2.7 \\
\hline Bauxite & -1.1 & 3.0 \\
\hline Tin & -1.8 & 3.2 \\
\hline Iron & -3.9 & 3.4 \\
\hline Coal & -5.5 & 4.0 \\
\hline Natural gas & -6.5 & 3.4 \\
\hline Petroleum & 3.9 & 1.0 \\
\hline
\end{tabular}

Nevertheless, the econometric results obtained do not seem to us to be very significant to us. They give only a very global idea of what the economic impact of disarmament means. However, the model of Leontieff and Duchin is not very adequate as a reflection of the ways in which the groups of countries under consideration were growing in 1990 . For example, the excellent results foreseen for the planned-economy countries are very wide of the mark, because the formalized system had to use optimistic figures (based on bureaucratic planned prices) supplied by the socialist governments, and it was scarcely possible to analyze the latent political and economic crisis of the Eastern countries on the basis of the raw official data.

2. Capelin, Bjerkholt and Gleditsch (1982) make several simulations of the World model, applying the same methods. 
They tested four main hypotheses: the base scenario, a true projection of the strategic and economic situation of the early eighties, a progressive reduction of military expenditure of the order of 15 percentage points every ten years, without any reconversion effort, and an equivalent reduction, but with either an internal reconversion effort, or a desire for conversion directed exclusively towards the developing countries. In the first case it is the developed countries that are the main beneficiaries of ongoing disarmament. With international aid, on the other hand, the gap between rich and poor countries tends to narrow (Table 3 ).

Table 3. Per Capita GDP in 1980 and 2000 (in US dollars of 1970)

\begin{tabular}{|l|r|r|r|r|r|}
\hline Type of country & 1980 & BASE & \multicolumn{1}{l|}{ IS } & REC.1 & REC.2 \\
\hline Donors & 1972 & 3388 & 3456 & 3459 & 3480 \\
\hline Beneficiaries & 172 & 186 & 197 & 317 & 440 \\
\hline Other regions & 837 & 1180 & 1224 & 1302 & 1392 \\
\hline $\begin{array}{l}\text { Developed } \\
\text { countries }\end{array}$ & 3323 & 5475 & 5655 & 5663 & 5709 \\
\hline $\begin{array}{l}\text { Resource-rich } \\
\text { countries }\end{array}$ & 711 & 1967 & 1829 & 1943 & 2059 \\
\hline $\begin{array}{l}\text { Developing } \\
\text { countries with few } 184 \\
\text { resources }\end{array}$ & 241 & 244 & 320 & 399 \\
\hline Total & 1115 & 1663 & 1701 & 1773 & 1842 \\
\hline
\end{tabular}

These simulations yield the same types of results and conclusions as those of Leontieff and Duchin, and the same criticisms may be levelled at them.

3. A simulation based on the UNITAD world model (Royer, 1985) simultaneously examines the economic impact of disarmament and of disarmament for development. In an initial scenario disarmament is not accompanied by an international redistribution of the amounts saved, while a second type of simulation studies a policy based on the satisfaction of basic needs (with the promotion of small-scale, highly productive economic activities in the developing countries).

Two cases are analyzed:

- disarmament that permits realization of the objective of public assistance for development amounting to 0.7 per cent of the GNP; 
- one third of world military expenditure is transferred to development programmes for the developing countries, partly through direct aid from the developed countries corresponding to an additional expression of solidarity of the order of one third of their savings on military expenditure, and partly through a transfer of internal allocations from military resources to civilian productive activities.

Job creation seems quite modest for the developed countries. But, the situation for the developing countries is very appreciably improved. Whereas the reduction of military expenditure depresses demand and causes an increase in unemployment in the short term, its spin-off is expressed in the longer term in the growth of the developing countries by an increase in demand for the most developed areas. If the improvement in the amount of international assistance is based on a policy that accords priority to basic needs, the result is considerable additional growth and job creation. These effects will be strengthened by measures for the easing of trade and currency restrictions. It should be noted, however, that these gains may rapidly become losses if this development is accompanied by an increase either in interest rates or in the amount of the annual repayments of the debt burden of the developing countries. Disarmament may relax some economic constraints (and may, in some cases, tighten them), but it cannot, on its own, resolve all the problems of the developing countries.

Thus, for example, even on the most satisfactory hypothesis, the real per capita consumption in Sub-Saharian Africa will continue to worsen because the population is growing at too fast a rate, and because of the endemic weakness of agricultural production. The material well-being of the African population cannot be improved without substantial improvements in agricultural productivity. Lastly, the governments of these regions have to realize that they must rely first and foremost on themselves to set their countries on the road to economic development.

Table 4. Simulations of the Economic Consequences of Disarmament for developing countries

\begin{tabular}{|l|c|c|}
\hline Hypotheses & \multicolumn{1}{|c|}{$\begin{array}{c}\text { Without income } \\
\text { redistribution }\end{array}$} & Basic needs \\
\hline $\begin{array}{l}\text { Disarmament with publid } \\
\text { assistance, } 0.7 \% \text { of GN }\end{array}$ & $\begin{array}{c}\text { mean growth per year } 8.9 \% \text { mean growth per } \\
\text { year }\end{array}$ \\
\hline $\begin{array}{l}\text { Disarmament, } 1 / 3 \text { of } \\
\text { military expenditure }\end{array}$ & $8.6 \%$ mean growth per year $\begin{array}{c}9.4 \% \text { mean growth per } \\
\text { year }\end{array}$ \\
\hline Hypotheses & Job created & Job created \\
\hline
\end{tabular}




\begin{tabular}{|l|c|c|}
\hline $\begin{array}{l}\text { Public assistance, O.7 } \\
\text { of GNP }\end{array}$ & 19 million & 127 million \\
\hline $\begin{array}{l}\text { Disarmament, 1/3 of } \\
\text { military expenditure }\end{array}$ & 73 million & 169 million \\
\hline
\end{tabular}

The situation for the developing countries is very appreciably improved

4. A specific version of the SARUM model (Gigengack, de Haan and Jepma, 1987) introduces the military sector into a world economic model inspired by the studies of Richardson (1960) and of Brito and Intriligator (1976). Several scenarios were analyzed in a situation of peace, of war, of peace with a strong incentive to investment, of world peace combined with strong expansion, and of war with governmental control of investment. These analyses are only secondarily concerned with the economic and social consequences of disarmament, especially as military expenditure may become endogenous variables in the model. The "Peace" scenario involves the hypothesis that the internal forces influencing military expenditure are decreased, particularly the pressures exerted by the military-industrial complex and the view of internal unrest taken by governmental elites. Under these conditions, Richardson's coefficients of response to external aggression are reduced, following which there is a heavy reduction in government budgets. Nevertheless, the growth rates of all the regions concerned increase. On the other hand, in a situation of voluntary reduction of military expenditure decided upon by NATO, and assuming proper conversion of the resources thus freed in the form of productive investments, military security is followed by economic security and the process of economic development begins in all regions.

5. The results yielded by the LINK model (Luckham) are not without interest. For example, a 10 per cent reduction of military expenditure accompanied by an improvement in international assistance put at 0.7 per cent of the GNP of the developed countries is capable, in the best case of a transfer relating exclusively to capital goods, of leading to a 1.7 per cent growth of the GNP in the developing countries and an 0.2 per cent growth in the developed countries. However, assistance is not always used advisedly. Should it be squandered, the growth rate of the developing countries would not experience any negative shock in the short term, but the developed countries would experience a negative effect of the order of 0.3 per cent of their annual growth. For this transfer to be positive for all parties (donors and recipients), 60 per cent of the aid must be expended on capital goods. But the collapse of the soviet economy reduces the quality of the information given by the model. 
In conclusion, current discussions of the potential of disarmament lead us to propose six rules ${ }^{4}$ that we believe will play an important role in governing the relationship between disarmament and economic processes. We do not offer these "rules" as ironclad, nor do we offer definitive proof for each of them. We believe that these ideas will have important consequences as disarmament unfolds.

Rule 1: The quantitative control of armaments entails no necessary implications for the reduction of financial efforts of states to insure their national security.

Rule 2 - The reduction of military expenditure is indispensable in every disarmament agreement.

Rule 3 : Disarmament by reduction of defence spending constraints will not be decided by a rule of proportionality and should be gradual.

Rule 4 - Military spending is at best a weak and incomplete indicator of the strategic strength of a state.

Rule 5 - If it is necessary to bear in mind the costs of peace as well as the peace dividends in the short term, it is possible to have peace investment in the long term, with political and strategic restructurations.

Rule 6: Reduction of military spending is a major political decision based on the premise of reciprocity among states.

If both peace and arms control are undertaken at all, this will be for political and not for economic reasons. Disarmament and development would appear to have simultaneous relationships, each being at the same time both the cause and the result of the other. Advocates of the New Economic Order see disarmament rather as a consequence of development. Underdevelopment is a threat to world peace.

If short term disarmament is highly desirable, the eradication of the main causes of wars and conflicts, such as inequalities, underdevelopment, injustices, domination effects, militarism, or nonrespect of human rights must be the the main guarantees for a peace society. The economy of disarmament does not stop at the mere reduction

${ }^{4}$ FONTANEL \& WARD: 
of military expenditure; it must also apply itself to the reasons on which the disarmament is based and which, if possible, make it irreversible. This latter point is not, however, one that can be tackled by economists on their own, for it involves consideration of the very nature of humankind.

\section{Bibliography}

- ABEN Jacques (1981) : "Désarmement, activité et emploi", Défense Nationale, Mai.

- ADAMS Gordon \& GOLD David (1985) : "The Economics of Military Spending. Is the military dollar really different ?", in "Peace, Defence and Economic Analysis", Schmidt \& Blackhaby (eds.), Mac Millan Press, London

- ANDERSON M., FRICH M. \& ODEN M. (1986) "The empty pork barrel. The employment cost of the military build-up". Employment Research Associates, Lansing Michigan.

- ATESOGLU S. \& MUELLER M.J. (1990) : "Defence Spending and Economic Growth". Vol. 2, no1. Harwood Academic Publishers, Chur et London.

- ATTALI Jacques (1978) : "La nouvelle économie française". Flammarion, Paris,.

- BALDWIN D.A. (1985): "Economic Statescraft". Princeton University. Princeton.

- BALL Nicole (1988) : "Security and economy in the Third World". Princeton University Press, Princeton.

- BARAN \& SWEEZY (1966) : "Monopoly Capital". Penguin Book, London.

- BENOIT Emile \& BOULDING Kenneth eds., (1963) ; "Disarmament and the Economy". Harper and Row, New York.

- BENOIT Emile (1967) : "Disarmament and World Economic Interdependence". Columbia University Press, New York.

- BENOIT Emile (1973) : "Defence and Economic Growth in Developing Countries". Boston, D.C. Heath, Lexington Books.

- BENOIT Emile (1978) : "Growth and defence in developing countries". Economic Development and Cultural Change, Vol. 26, January, pp. 271-280.

- BISCHAK Gregory \& ODEN Michael (1989) : "The INF Treaty and the United States' experience: the industrial, economic and employment impacts". Disarmament and Employment Programme, Working Paper $n^{\circ} 11$, International Labour Office, Geneva, April 1989.

- BOUTHOUL G. (1961) : "Sauver la guerre", Grasset, Paris. 
-BRITO, D., INTRILIGATOR, M. (1987), Arms race and the outbreak of War. International Economic Association, Stockholm, Mac Millan Press, London.

- CAPPELEN, GLEDITSCH, NJERKHOLDT (1984), Military Spending and Economic Growth, Journal of Peace Research, $n^{\circ} 4$.

- CARS, H.C., FONTANEL, J. (1987), Military Expenditure Comparisons, in «Peace, Defence and Economic Analysis (Schmidt, C. \& Blackhaby, F. Ed.), Mac Millan Press, London.

CHAN, S., MINTZ, A. (1991), Defence, Welfare and Growth, Unwin Heyman, Boston, MA.

- COLARD, D., FONTANEL, J. , GUILHAUDIDS, J-F. (1981), Le désarmement pour le développement, un pari difficile, Fondation pour les Etudes de Défense nationale, Les Sept Epées, Paris.

- COOPER, J. (1988), The scales of output of civilian products by enterprises of the Soviet Defense industry, SITS Paper $\mathrm{n}^{\circ} 3$ - University of Birmingham.

- DEGER S., WEST, R. (1987), Defence, Security and development ; Frances Pinter, London.

- DUNNE, J.P., SMITH, R.P. (1984), The economic consequences of Reduced UK military expenditure, Cambridge Journal of Economics, September.

- FONTANEL, J. (1980), Military expenditures and Economic Growth (France, Morocco), Rapport pour le Groupe d'Experts des Nations Unies « Désarmement pour le Développement », CEDSI, Grenoble.

- FONTANEL, J. (1984), L'économie des armes, La Découverte, Paris.

- FONTANEL, J., SMITH, R. (1985), L'effort économique de défense, ARES, ${ }^{\circ}$ Spécial. Grenoble, Lyon.

- FONTANEL, J. (1985), L'intérêt d'un Fonds International de Désarmement pour le Développement, Etudes Internationales, vol 16, n³, Septembre

- FONTANEL, J. (19865), The International Disarmament Fund for Development, Disarmament, vol.IX, $\mathrm{n}^{\circ} 1$, Spring ? United Nations.

- FONTANEL, J., SMITH, R. (1987), The creation of an international disarmamentv fund for development, in «Defence, Security and Development (Deger \& West Editors), France Pinters, London.

- FONTANEL, J. (1990), L'économie du désarmement, Stratégique, n47, 3/90. Paris.

- FONTANEL, J. SMITH, R. (1990), The impact of strategy and measurement on models of French military expenditure. Defence Economics, $\mathrm{n}^{\circ} 1$.

- FONTANEL, J., WARD, M. (1991), Military expenditures, Armaments and Disarmaments, Defence Economics, à paraître.

- FREDERICKSEN, P.C., LOONEY, R.E. (1986), Defence expenditures, Esternal Public Debt and Growth in Developing Countries, Journal of Peace Research, December.

- GLEDITSCH, N.P., BJERKHOLT, O., CAPPELEN, A. (1987), Military R\&D and Economic Growth in Industrialized Market Economies, Journal of Peace Research.

- GRIFFIN, L.J., WALLACE, M., DEVINE, J. (1982), The political Economy of military spending : Evidence from United States, Cambridge Journal of Economics, $\mathrm{n}^{\circ} 6$.

- GYIMAH-BREMPONG, K. (1989), Defence spending and economic growth in Subsaharian Africa : an econometric investigation. Journal of Peace Research.

- HEWITT, D.P. (1991), Military Expenditure, Econometric Testing of Economic and Political Influences, Fiscal Affairs Department, IMF, May.

- KEYNES, M (1921), How to pay for war », London.

- KLEIN, L.R. (1990), Disarmament and Development » in Science, war and peace (J.J.. Solomon ed.), Economica, Paris. 
- LENINE (1922), L’impérialisme, stade suprême du capitalisme, Editions sociales, Paris, 1971.

- LEONTIEV, W., HOFFENBERG, M. (1961), The Economic Effects of Disarmament, Scientific American, $\mathrm{n}^{\circ} 204$, April.

- LEONTIEV \& DUCHIN (1983), Military spending : Facts and Figures. Worldwide implications and the Future Outlook, Oxford University Press.

- MELMAN, S. (1974)-, The permanent war economy: American capitalism in decline, Simon and Schuster, NY.

- ONU (1981), Etude sur les rapports entre le désarmement et le développement, sous la direction d'Inga Thorsson, A/36/356, Septembre.

- ONU (1981), La réduction des budgets militaires, Série 4? New York.

- ONU (1983), Conséquences économiques et sociales de la course aux armements et des dépenses militaires, ONU. F.83.IX.2

- ONU (1985), La reduction des dépenses militaires, Série 10, New York.

- NINCIC, M. CUSACK, T.R. (1979), The Political Economy of the US Military Spending, Journal of Peace Research, vol 16, $n^{\circ} 2$.

- OLSON, M. , ZECKHAUSER, R. (1966), An economic theory of alliances, Review of Economics and Statistics. 48.

- RICHARDSON, L.F. (1960), Arms and insecurity, Benwood, New York.

- SCHELLING, T. (1966), Arms and influence, Yale University Press, New Haven.

- SCHMIDT, C. (1987), The Economics of Military Expenditures, International Economic Association, Mac Millan Press, London.

- Schmidt, C., BLACKHABY, F. (1987), Peace, Defence and Economic Analysis, Mac Millan Press, London.

- SEN, A. (1983), Development: Which way now?, Economic Journal, vol 93, December.

- SMITH, R \& R. (1983), The Economics of Militarism, Pluto Press, London.

- SMITH, R ?, HUMM, A., FONTANEL, J. (1985) The Economics of exporting arms, Journal of Peace Research, Norvegian University Press, Oslo, September 1985, (10 pages).

- SMITH, R., FONTANEL, J. (1987), Capital-Labour substitution in defence provision", in "Defence, Security and Development", (DEGER \& WEST, Ed.), Francis Pinter, London, June 1987

- SMITH, R., MARTIN, J, Fontanel, J. (1987), Time-Series estimates of the macroeconomic impact of Defence spending in France and Britain. Colloque Association Internationale de Sciences Economiques et du SIPRI, Stockholm, Octobre 1985, in "Peace, Defence and Economic Analysis" (SCHMIDT C. \& BLACKHABY F., Ed). The International Economic Association, Mac Millan, London, 1987

- SMITH, R. (1989), Models of Military Expenditures, Journal of Applied Econometrics, Vol O.

- TREDDENICK, J. (1987), The Arms race and Militarian Keynesianism, Canadian Public Policy, Vol. XI. N 1 . March.

- UNIDIR (1984), Désarmement-développement, au delà des impasses, quelques suggestions pratiques, UNIDIR, Geneva. UNIDIR/96/13

- USACDA (1990), World Military Expenditures and Arms Transfers, Washington, D.C.

- VARAS, A. (1986), Military Spending and The Development Process., Disarmament, Vol IX. 3. Autumn. UNO.

- WARD, M. (1991), Military Technologies and Economic Development. A Comparison of India and Brazil, ARES, Grenoble. 
